\title{
ANALYSIS OF SELF-ORGANISING NETWORKS OF COMMUNICATION BETWEEN THE PARTICIPANTS OF A HOUSING COMPLEX CONSTRUCTION PROJECT
}

\author{
G. ŚLADOWSKI ${ }^{1}$, E. RADZISZEWSKA-ZIELINA, E. KANIA
}

\begin{abstract}
The article highlights the fact that numerous key decisions in temporary construction organisations are made as a result of informal, non-contractual relationships between organisation members that are not a result of formal organisational structures. These hidden relationships can be visualised in the form of social networks and Social Network Analysis methods (SNA) can be used to perform their structural analysis. In latest studies on self-organising networks in the construction sector, researchers have mostly focused on the design phase of large construction projects, e.g. infrastructural ones. Meanwhile, there exists a need for similar research to focus on temporary organisations created for the purpose of performing construction work. The authors took up this subject and examined a self-organising network of communication between the participants of the construction of a multi-family residential complex located in Katowice, Poland. The structural analysis of this network facilitated its in-depth understanding and identifying certain flaws and dysfunctions concerning individual participants of this project, which became a basis for further discussion. At the same time, the authors highlighted the benefits of managing such a self-organising network in the context of the effective achievement of project goals.
\end{abstract}

Keywords: Social network analysis (SNA), construction management, construction works

\section{INTRODUCTION}

The traditional approach to construction project management is primarily focused on planning tasks along with assigning renewable (general contractor, personnel, machinery) [1] and non-renewable resources (materials, financial means) to them. Over the course of the carrying out of a construction project, attention is focused on organising resources and monitoring the execution of tasks, along with controlling any deviation from the plan and budget, as well as with any corrective action that might be taken. The various management techniques employed here consider informal interpersonal relationships that form over the course of a project's execution during analysis. Meanwhile, many key decisions are being made as a result of informal relationships that are outside of the bounds of a project's contract or the formal organisational structure of relationships between the participants of a construction project [2]. An informal community of participants forms over the course of the execution of a construction project, whose actual

\footnotetext{
${ }^{1} \mathrm{PhD}$, Eng., Cracow University of Technology, Faculty of Civil Engineering, Institute of Construction Management, gsladowski@L3.pk.edu.pl
} 
behaviour and role within the project are not a result of contractual and organisational relationships, but are a function of hidden interactions between participants. These informal relationships are dynamic, as they undergo constant change and adapt so as to facilitate the achievement of project goals. Understanding these formal relationships and identifying any improper behaviours and roles of participants that could adversely affect the effective achievement of project goals requires this problem to be conceptualised in the form of a network of social relationships between project participants $[3,4]$.

One popular method of mapping the previously mentioned interpersonal relationships is the use of graphbased social networks analysed using the SNA method (Social Network Analysis). The concept of SNA was first developed by sociometry, introduced in the previous century by J.L. Moreno [5] a student of Sigmund Freud. Studies of social interactions in small organisations became the foundation for such terms like centrality and isolation within an organisation's structure. Since that time the concept of networks and their analysis have found use in numerous disciplines, such as, for instance, sociology, economy, anthropology, epidemiology, information science or management. In SNA we can distinguish two research approaches. The first approach focuses on social networks primarily in the context of their structure and the understanding of social phenomena that take place within them [6]. The second approach focuses its attention on the mathematical and statistical analysis of social networks and interpreting them using structural measures for said networks by [7].

One of the first applications of SNA in construction pertained to communication problems between the most essential personnel involved in a project, i.e. clients, project managers, architects and site managers $[8,9]$. The research field of the application of SNA in construction is varied. For instance, [10] studied the influence of types of orders on the effectiveness of construction project management using SNA. The work by [11] studied the dependency between spreading integrated knowledge and the link structure within a network. In turn, [12] investigated the frequency and manner of communication and the influence of the relationship structure on its effectiveness within specialist work brigades in the context of workplace health and safety. The researchers [13] analysed innovation awareness and influence on its adoption and spread among construction companies. Meanwhile [14] studied the possibility of using SNA to identify network gaps. In the work of [15] Public and Private Partnership projects in construction were analysed using SNA. In turn, [16] analysed project structures in the context of knowledge management, discussing whether the process of knowledge gathering, transfer and learning within a project environment is strongly based on social patterns, practices and processes. In the work by [17], the authors investigated relationships (in the context of knowledge exchange) in multi-cultural projects (they discussed the problem of network globalisation). One of the newer works by [18] concerned the analysis of correlations between degree centrality of construction brigades and productivity in the carrying out of joint tasks with other brigades. The analysis took into consideration the dynamic of the process (weekly project monitoring). Meanwhile, [19] pointed their attention to benefits that are gained by supporting strong cooperation relationships $[20,21,22]$ between participants, particularly in large projects.

The abovementioned examples can be used to confirm the potential of the application of networks in construction. Numerous benefits and values associated with organisation network management using SNA have been identified, such as improvements in communication and coordination, knowledge and innovation management, risk management and IT use.

However, there is a need for further empirical research that could aid researchers in understanding the formal and informal relationships between project participants and developing methods of detecting communication problems (at an early stage), focusing on team structure and information diffusion [23,24]. 
Identifying and understanding informal project participant roles that are dependent on their position within a network is thus a starting point for managing such an organisation as a part of executing a project.

\section{RESEARCH GOAL}

The latest studies on formal and informal relationships between construction project participants primarily focused on detecting communication and cooperation problems within a complex and temporary environment (a self-organising participant network) during the design phase of an infrastructural construction project based on expanding the potential of the Bank station along a line of the metropolitan underground railway in London [24]. The adoption of a network approach enabled the authors to compare a formally established organisational project hierarchy with the actual informal relationships between its participants.

However, the study focused on a self-organising network of participants only during the design phase of the project. It is necessary to advance this research, this time focused on relationships between participants during the project construction phase, which also involves other actors that do not take part in preparing the design of a project. The results of such research could provide valuable information on communication and cooperation during this project phase.

To this end, the authors of this article performed research based on comparing the formally established organisational structure of a project with actual informal relationships between its participants during the construction phase of said project. The authors analysed the effectiveness of communication between participants (transferring information about design scope and solutions, errors and missing items in the design and the possibility and scope of introducing changes to it) during the phase of performing work on finishes during the carrying out of a construction project involving the building of a housing complex in Katowice, Poland.

The research is meant to demonstrate the usefulness of the network-based approach and SNA analysis in detecting problems in communication between project participants and, as a result, facilitate a better understanding of the functioning of self-organising networks during the construction phase of a development project.

\section{RESEARCH DESCRIPTION}

\subsection{CONTRACTUAL RELATIONS AND THE FORMAL ORGANISATIONAL STRUCTURE OF THE} ANALYSED PROJECT

The construction project that was analysed featured the construction of a complex of multi-family residential buildings located in the northern part of Katowice (around 3,5 $\mathrm{km}$ from the city centre). The complex included four six-storey buildings (ca. $12000 \mathrm{~m}^{2}$ of usable floor area) with commercial premises on ground floors, underground parking garages as well as technical and road infrastructure. The project's construction phase began in the first half of 2016 and its completion was planned for 2019. The project 
budget is 40 million PLN. The first of the buildings has already been completed and made available for use, while the remaining three are under construction (Phot. 1). The project was governed using the general contractor system up to September 2018.

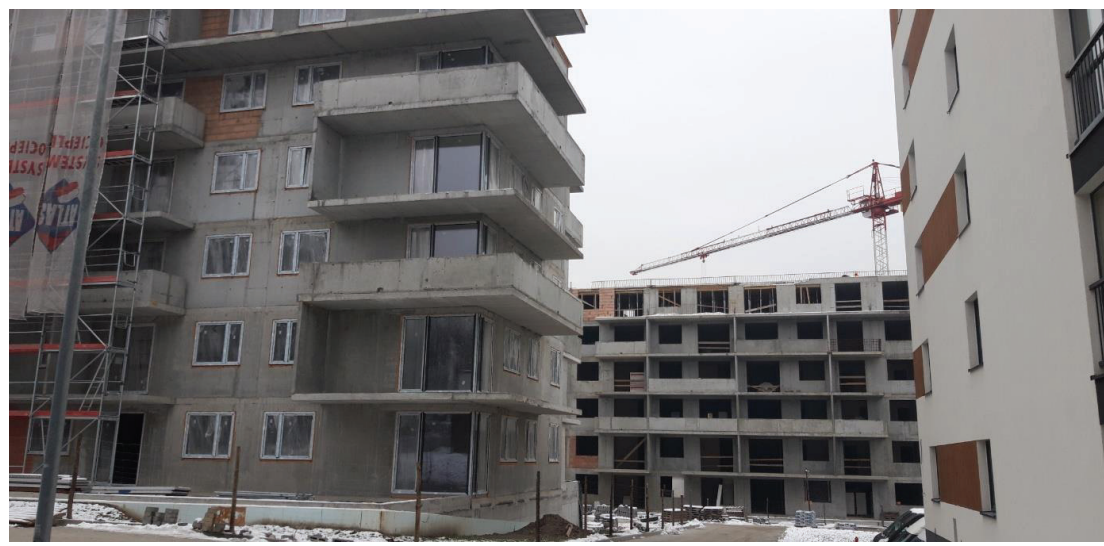

Phot.1. View of the project site

However, as a result of the current situation on the construction market (high construction material and service prices and the lack of qualified construction personnel) the General Contractor of the project was forced to declare bankruptcy, which led to the Developer and General Contractor to end their cooperation. The Developer made the decision to complete the project by employing management personnel and signing agreements with construction companies directly. The new contractual relationships between the parties (organisations) have been shown on figure 1. The effect of these changes was the necessity to remodel the previous formal organisational structure into a new one (figure 2).

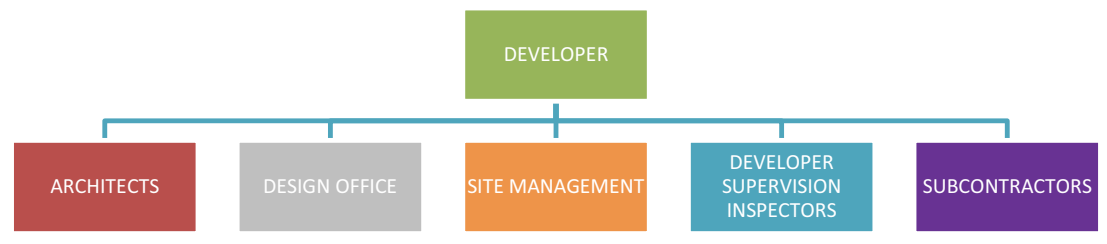

Fig. 1. Contractual hierarchy structure of the organisations taking part in the construction of the multifamily residential building complex in Katowice (November 2018) 


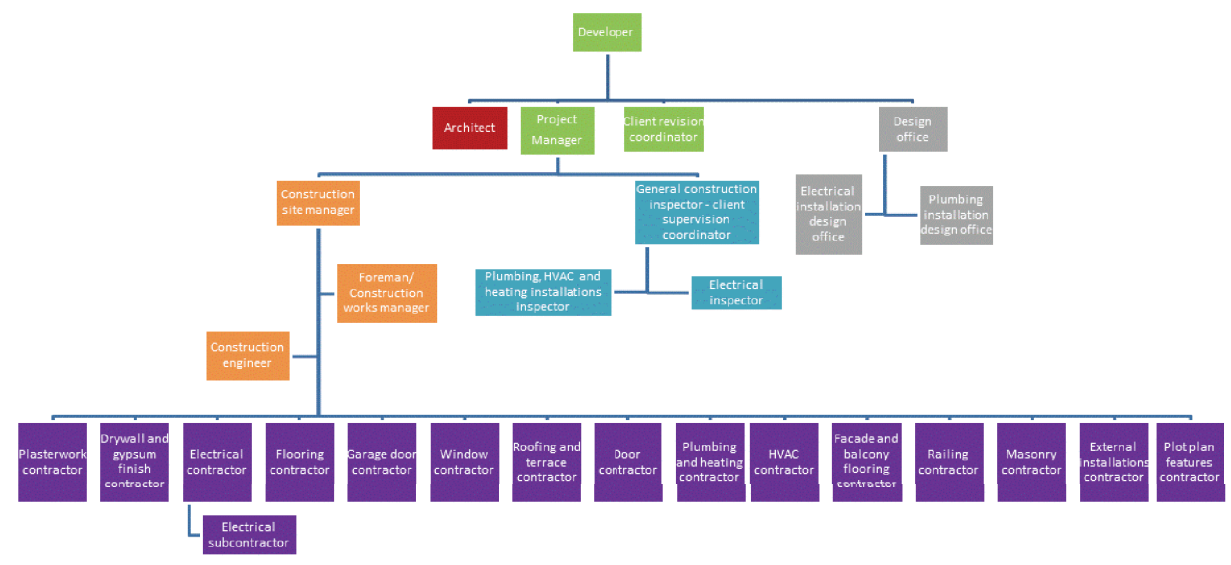

Fig. 2. Formal project organisation structure

\subsection{IDENTIFICATION OF THE SELF-ORGANISING NETWORK OF COMMUNICATION BETWEEN PROJECT PARTICIPANTS}

The study was performed one month after the restructuring of the construction project in question. Data was gathered (using the questionnaire survey method) from all 28 project participants. In the case of this study, the project participants included both individuals (e.g. Site Manager or Project Manager), as well as organisations that had their representatives in charge of communication (e,g, construction companies, design offices). The participants were asked to identify persons with whom they had had contact with concerning design scope and solutions, any missing items or errors in the design, as well as the possibility and scope of introducing changes concerning the finishing work being performed at the time. For the purposes of the study it was assumed that communication using e-mail, phone, by post or in the form of a face-to-face conversation are jointly represented as relationships/links between two actors.

The verbal description of the communication structure between project participants has been presented using a relationship network. The nodes of the network symbolise individuals or organisations and the arcs signify directions of communication between them.

In the case being discussed, the weight of communication (the load placed on a network arc) is defined by two variables: frequency and quality [24]. In order to determine communication frequency and quality, the authors used the Likert scale. A five-point rating of communication frequency (less than once per week, once per week, several times per week, once per day, more than once per day, rated 
from 1 to 5 points, respectively), as well as a three-point rating scale for communication quality (poor, average, high) were adopted. Quality was measured using three measures: importance, accuracy and timeliness.

Using the pattern employed in [24], communication weight between nodes $i$ and $j$ was expressed as:

$$
E_{i j}=F_{i j} \cdot Q_{i j},
$$

Where:

$F_{i j}=f_{i j} / 5$, is the frequency of communication as a measure of $f_{i j}$ normalised to be between 0 and 1 , and $Q_{i j}=q_{i j} / 9$, is the quality of communication, which is the arithmetic mean of the aforementioned three quality measures $q_{i j}$ normalised to be between 0 and 1 . Following [24] for simplicity, all parameters were considered to be equally important.

In the case when communication between two participants is not reciprocal, then the weight of communication is reduced in accordance to the formula:

$$
\text { if }\left(E_{j i}=0\right) \text { then } E_{i j}=E_{i j} \cdot a \text {, }
$$

Where: " $a$ " is a constant factor employed in order to adapt the value of arcs without reciprocal links. According to [24] a value of $10 \%$ was assumed for "a".

The results that had been obtained were used to construct a neighbourhood matrix, followed by using the Gephi computer program to visualise the self-organising communication network between the project's participants.

\subsection{NETWORK STRUCTURAL ANALYSIS AND CONCLUSIONS}

The structural analysis of the obtained informal relationships network focusing on communication on the subject of design scope and solutions, missing items or errors in the design, as well as the possibility and scope of changes concerning the finishing work being carried out at the time of the study, was based on distinct network structural measures, including:

- density,

- degree centrality,

- betweenness,

- closeness

- modularity.

Density is the measure of a network's cohesion and is defined as the number of existing ties (symbolised by arcs) divided by the number of all possible ties (relationships) within a network. The value of density ranges between 0 and 1 . A high cohesion within a network is most often interpreted as an increase in communication effectiveness within the analysed organisation. However, a portion 
of researchers have proven that excessive cohesion within a network can take place as a result of there being too many redundant communication links between organisation members, which can lead to information chaos or group think, etc. [25]. For the analysed network of the construction project in question, the density value was 0.298 , which denotes a level of networking that is not too high, although this can be a result of this being an early phase (first month) of the emergence of the selforganising participant network of this project.

The second of the measures being discussed is degree centrality. It is the number of links that a given node has with other nodes. The higher the degree centrality, the more important a particular node is within the network. Within degree centrality itself we can differentiate in-degree and outdegree centrality of a node, defined using the number of inbound and outbound arcs of a given node.

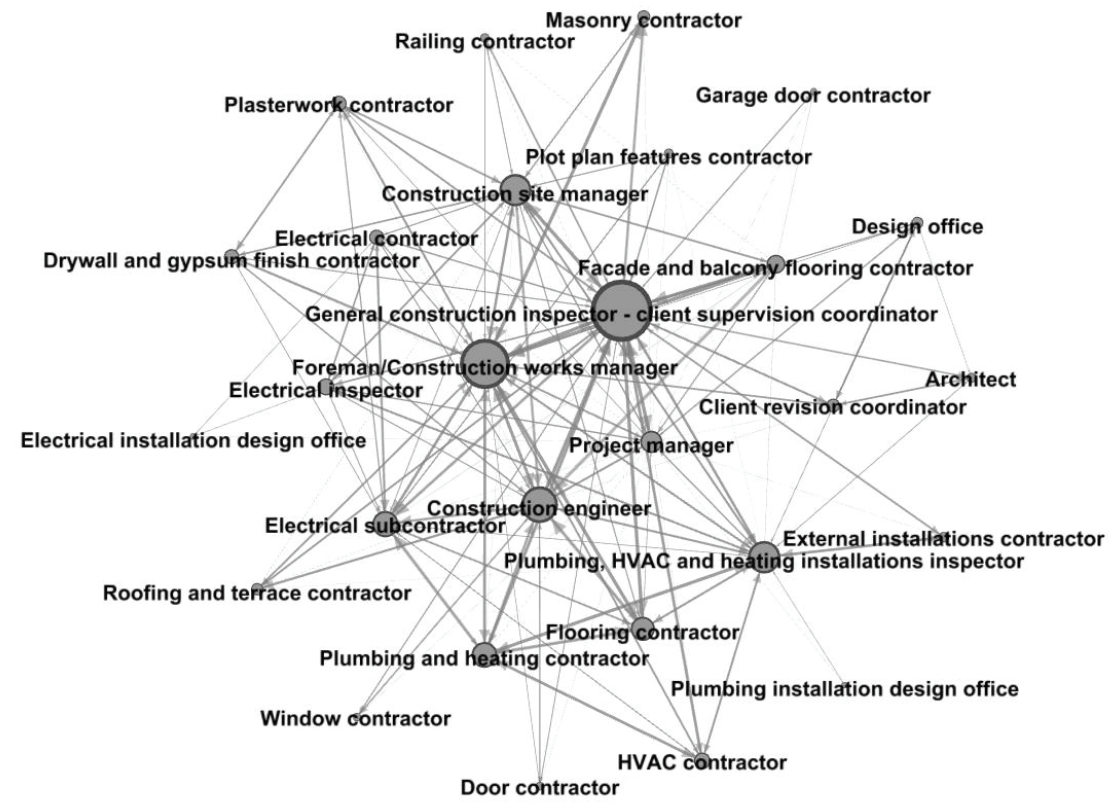

Fig. 3. Weighted degree centrality value of nodes (defined by the diameter of a node, the larger the diameter the greater the value of this measure) in the self-organising network of communication between project participants

When analysing a network node's degree centrality (fig. 3 and table 1) we observed a disproportionally high degree centrality of the Developer Supervision Coordinator relative to other participants. The importance of the Project Manager (a representative of the Developer) was quite low, which in this case was probably caused by his main task being the management of finance, with technical matters (communication in the context of analysing design scope and solutions, any missing items or errors in the design and the possibility and scope of introducing changes) being of secondary 
importance to them. The low degree centrality of Design Offices could have been caused by there being no design errors communicated by other participants at the stage of finishing work that was being carried out at the time of the study. However, the low degree centrality of the Site Manager was quite surprising, as this position should be at least equal to that of the Developer Supervision Coordinator in terms of communication concerning technical matters. At the same time we can observe a high degree centrality of the Foreman/Construction Works Manager, which was probably caused with them being directly responsible for managing finishing works. In addition, it should be noted that the Construction Engineer (as an assistant of the Site Manager) is not a decision-maker, which is why their importance should be much lower than that of the Site Manager.

Betweenness is a very important measure in the context of analysing communication within a network. A given node's betweennness is defined by the relation between the number of shortest paths between any two nodes that cross the given node and the sum of the number of all of the network's shortest paths.

The value of this measure points to the Developer Supervision Coordinator as the person who engaged in the highest amount of brokering in receiving and passing on information concerning design scope and solutions, any missing items or errors in the design and the possibility and scope of changes introduced as a part of the finishing works being performed (table 1). This constitutes a significant flaw. A network with a single leader in both receiving and disseminating information is highly susceptible to disruption caused by severing of information channels within the network that might be caused by, for instance, said person not being present during key moments. However, the fact that we can consider this person a broker who transfers a similar amount of information to that which they receive, without blocking its flow, can be considered positive. A much higher degree betweenness in the flow of information within the network should, however, be expected of the Site Manager and Project Manager.

The closeness of a given node is defined as the average length of the shortest paths between the given node and all remaining nodes within the network. A node with a high closeness makes it easier for information to reach other nodes.

When analysing this communication network from the perspective of this measure we can observe that the majority of the most essential participants have similar values (table 1.) 
Table. 1. Weighted network structural measures of nodes in the self-organising network of between project participants

\begin{tabular}{|c|c|c|c|c|c|}
\hline Node & $\begin{array}{l}\text { weighted } \\
\text { indegree }\end{array}$ & $\begin{array}{l}\text { weighted } \\
\text { outdegree }\end{array}$ & $\begin{array}{l}\text { weighted } \\
\text { Degree }\end{array}$ & $\begin{array}{c}\text { weighted } \\
\text { betweenness } \\
\text { centrality }\end{array}$ & $\begin{array}{l}\text { weighted } \\
\text { closeness } \\
\text { centrality }\end{array}$ \\
\hline General construction inspector - client supervision coordinator & 13.94 & 15.76 & 29.7 & 394.50 & 0.31 \\
\hline Electrical inspector & 3.23 & 2.72 & 5.95 & 25.0 & 0.20 \\
\hline Plumbing, HVAC and heating installations inspector & 7.18 & 6.84 & 14.02 & 91.33 & 0.26 \\
\hline Project manager & 4.11 & 4.53 & 8.64 & 24.0 & 0.25 \\
\hline Construction site manager & 6.58 & 7.34 & 13.92 & 10.17 & 0.26 \\
\hline Foreman/Construction works manager & 12.3 & 11.03 & 23.33 & 117.00 & 0.27 \\
\hline Construction engineer & 9.17 & 7.12 & 16.29 & 64.33 & 0.26 \\
\hline Architect & 1.44 & 0.76 & 2.2 & 0.0 & 0.14 \\
\hline Client revision coordinator & 1.93 & 2.23 & 4.16 & 25.0 & 0.22 \\
\hline Design office & 1.61 & 1.67 & 3.28 & 0.0 & 0.18 \\
\hline Electrical installation design office & 0.13 & 0.34 & 0.47 & 0.0 & 0.10 \\
\hline Plumbing installation design office & 0.06 & 0.18 & 0.24 & 0.0 & 0.12 \\
\hline Plasterwork contractor & 2.37 & 2.8 & 5.17 & 0.0 & 0.22 \\
\hline Drywall and gypsum finish contractor & 2.39 & 2.64 & 5.03 & 0.0 & 0.21 \\
\hline Electrical contractor & 5.09 & 4.58 & 9.67 & 28.0 & 0.19 \\
\hline Electrical subcontractor & 0.49 & 0.18 & 0.67 & 5.0 & 0.21 \\
\hline Flooring contractor & 0.95 & 0.36 & 1.31 & 0.0 & 0.26 \\
\hline Garage door contractor & 1.67 & 1.8 & 3.47 & 0.0 & 0.12 \\
\hline Window contractor & 0.73 & 0.72 & 1.45 & 0.0 & 0.12 \\
\hline Roofing and terrace contractor & 4.17 & 6.36 & 10.53 & 0.0 & 0.22 \\
\hline Door contractor & 2.62 & 3.18 & 5.8 & 0.0 & 0.15 \\
\hline Plumbing and heating contractor & 2.73 & 4.15 & 6.88 & 3.0 & 0.27 \\
\hline HVAC contractor & 1.05 & 0.81 & 1.86 & 0.0 & 0.25 \\
\hline Facade and balcony flooring contractor & 2.22 & 1.56 & 3.78 & 0.0 & 0.26 \\
\hline Railing contractor & 1.33 & 1.16 & 2.49 & 0.0 & 0.15 \\
\hline Masonry contractor & 1.1 & 1.03 & 2.13 & 0.0 & 0.21 \\
\hline External installations contractor & 1.33 & 1.16 & 2.49 & 0.0 & 0.20 \\
\hline Plot plan features contractor & 1.1 & 1.03 & 2.13 & 0.0 & 0.17 \\
\hline
\end{tabular}

The modularity is the density of the direct neighbouring placement of a given node for which its neighbourhood is defined as a set of all nodes that are directly connected to it. Determining the modularity makes it possible to identify communities within the network. 


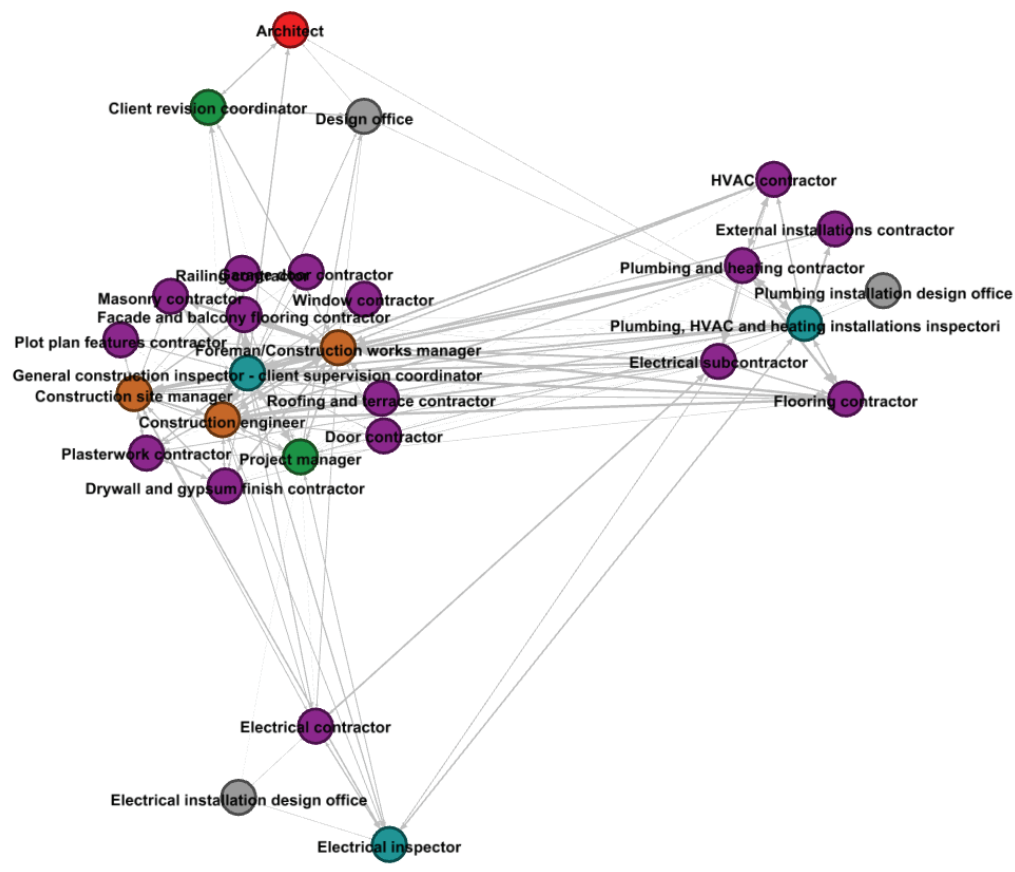

Fig. 4. Weighted modularity (the colors of the nodes in the network correspond to the colors from the contractual structure and the formal organizational structure of the enterprise)

The authors observed the formation of communities that cooperated closely within their branches of work (general construction, electrical installations and plumbing), as well as a separate community formed by designers and the Client Revision Coordinator (fig. 4).

Detailed analysis pointed to at least two specific situations that require in-depth investigation:

1. There is no direct communication between Design installation offices and the main Design Office. For example: The Electrical Installation Design Office did not communicate directly with the main Design Office only with the Electrical Installation Contractor and the Developer Supervision Inspector.

2. The participation of the Electrical Installations Subcontractor in the group formed by plumbing, HVAC and central heating contractors was also puzzling, as it signified closer contact with them than with the main Electrical Installation Contractor. Perhaps the behaviour of this subcontractor was determined by numerous small clashes between the electrical installation and the remaining installations. However, the presence of Floor Contractor in this group seems to be more justified by the fact that most sanitary installations are carried out in floor layers. 


\section{CONSLUSIONS}

As a result of the analysis performed by the authors, it was demonstrated (in the context of transferring information concerning: design scope and solutions, missing items or errors in the design, as well as the possibility and scope of introducing design changes) that within a self-organising network of project construction phase participants, communication can significantly differ from the form of communication defined by organisations. As a result of the analysis, a hidden "community" structure was revealed, whose members clustered into smaller groups as a part of fulfilling their tasks. When analysing the network in question on the basis of fundamental structural measures, the authors noted various abnormalities in communication, which should be subjected to detailed investigation. Of note is the fact that informal hidden relationships between participants are dynamic, as they constantly change (evolve) and adapt so as to achieve project goals. It is thus essential to monitor these self-organising networks throughout the entire cycle of carrying out the project. The systematic detection of various dysfunctions among project participants within the analysed network can become a justification for organisation management personnel to intervene into the relationship structure between these participants. Focusing on managing this self-organising network can bring greater benefits in the context of achieving project goals than using formal and contractual relationships (imposed by organisational structures established at a superior level) between participants [24]. Directions of further research should focus on developing more effective, reliable methods of obtaining data for visualising (in network form) hidden relationships between project participants, as survey studies have their inherent limitations. Studies should also continue on simultaneously analysing various contexts of communication between the participants of a given project, which should facilitate a broader understanding of the characteristics of self-organising networks during a project's construction phase. Alternatively, management intervention into this hidden project participant relationship structure should be optimised in the context of set goals and take into consideration (particularly essential during the early stages of an organisation's development) constraints such as the cost of communication within a given organisation [26]. To this end, there appears the need to develop effective optimisation methods that would support said interventions into the structure of such networks.

\section{REFERENCES}

[1] Ksiażek, M., Ciechowicz, P. "Selection of the General Contractor Using the AHP Method" Archives of Civil Engineering 62.3 (2016): 105-116

[2] Ksiażek, MV, Nowak, P., Kivrak, S., Roslon, JH., Ustinovichius, L „Computer-aided decision-making in construction project development” Journal of Civil Engineering and Management, 21(2), 248-259, 2015

[3] Winter, Mark, et al. "Directions for future research in project management: The main findings of a UK government-funded research network." International journal of project management 24.8 (2006): 638-649.

[4] Hanisch, Bastian, and Andreas Wald. "A project management research framework integrating multiple theoretical perspectives and influencing factors." Project Management Journal 42.3 (2011): 4-22.

[5] Moreno, Jacob Levy. "Who shall survive?: A new approach to the problem of human interrelations." (1934).

[6] Scott, John. Social network analysis. Sage, 2017.

[7] Wasserman, Stanley, and Katherine Faust. Social network analysis: Methods and applications. Vol. 8. Cambridge university press, 1994. 
[8] Loosemore, Martin. "Construction crises as periods of social adjustment." Journal of management in engineering 13.4 (1997): 30-37.

[9] Loosemore, Martin. "Social network analysis: using a quantitative tool within an interpretative context to explore the management of construction crises." Engineering, construction and architectural management 5.4 (1998): 315-326.

[10] Pryke Stephen . Social network Analysis in Construction, Wiley-Black Well, 2012.

[11] Ruan, Ximing, et al. "Knowledge integration process in construction projects: a social network analysis approach to compare competitive and collaborative working." Construction Management and Economics 30.1 (2012): 5-19.

[12] Alsamadani, Rayyan, Matthew Hallowell, and Amy Nicole Javernick-Will. "Measuring and modelling safety communication in small work crews in the US using social network analysis." Construction Management and Economics 31.6 (2013): 568-579.

[13] Larsen, Graeme D. "Understanding the early stages of the innovation diffusion process: awareness, influence and communication networks." Construction Management and Economics 29.10 (2011): 987-1002.

[14] El-Sheikh, Ahmed, and Stephen D. Pryke. "Network gaps and project success." Construction management and economics 28.12 (2010): 1205-1217.

[15] Chowdhury, Abu Naser, Po-Han Chen, and Robert LK Tiong. "Analysing the structure of public-private partnership projects using network theory." Construction Management and Economics 29.3 (2011): 247-260.

[16] Brookes, N. J., et al. "Social processes, patterns and practices and project knowledge management: A theoretical framework and an empirical investigation." International Journal of Project Management 24.6 (2006): 474-482.

[17] Di Marco, Melissa K., John E. Taylor, and Pauli Alin. "Emergence and role of cultural boundary spanners in global engineering project networks." Journal of management in engineering 26.3 (2010): 123-132.

[18] Abbsaian-Hosseini, S. Alireza, Min Liu, and Simon M. Hsiang. "Social network analysis for construction crews." International Journal of Construction Management (2017): 1-15.

[19] Mok, Ka Yan, Geoffrey Qiping Shen, and Jing Yang. "Stakeholder management studies in mega construction projects: A review and future directions." International Journal of Project Management 33.2 (2015): 446-457.

[20] Radziszewska-Zielina, E., and B. Szewczyk. "Supporting partnering relations management in construction projects' implementation using AHP and Fuzzy AHP." Procedia Engineering 161 (2016): 1096-1100.

[21] Radziszewska-Zielina, E. "Assessment Methods of Partnering Relations of Polish, Slovak and Ukrainian Construction Enterprises with the Use of Fuzzy Logic/Metodyka Oceny Relacji Partnerskich Polskich, Słowackich I Ukrainskich Przedsiebiorstw Budowlanych Z Wykorzystaniem Logiki Rozmytej." Archives of Civil Engineering 57.1 (2011): 87-118.

[22] Radziszewska-Zielina, E., E. Kania, and G. Śladowski. "Problems of the Selection of Construction Technology for Structures in the Centres of Urban Agglomerations." Archives of Civil Engineering 64.1 (2018): 55-71.

[23] Malisiovas, Andreas, and Xinyi Song. "Social Network Analysis (SNA) for Construction Projects' Team Communication Structure Optimization." Construction Research Congress 2014: Construction in a Global Network. 2014

[24] Pryke, Stephen, et al. "Self-organizing networks in complex infrastructure projects." Project management journal 49.2 (2018): 18-41.

[25] Wise, Sean. "Can a team have too much cohesion? The dark side to network density." European Management Journal 32.5 (2014): 703-711.

[26] Pryke, Stephen. Managing networks in project-based organisations. John Wiley \& Sons, 2017.

\section{LIST OF FIGURES AND TABLES:}

Phot.1. View of the project site

Fotografia 1. Widok placu budowy osiedla mieszkaniowego.

Fig. 1. Contractual hierarchy structure of the organisations taking part in the construction of the multi-family residential building complex in Katowice (November 2018)

Rys. 1. Struktura umowna pomiędzy organizacjami budowy osiedla mieszkaniowego wielorodzinnego w Katowicach ( listopad 2018)

Fig. 2. Formalna struktura organizacyjna przedsięwzięcia

Fig. 2. Formal project organisation structure 
Fig. 3. Degree centrality value of nodes (defined by the diameter of a node, the larger the diameter the greater the value of this measure) in the self-organising network of communication between project participants Rys. 3. Wartość stopnia centralności węzłów (określona średnicą węzła im większa średnica tym wyższa wartość tej miary) w samoorganizującej się sieci komunikacji pomiędzy uczestnikami przedsięwzięcia

Table 1 Weighted network structural measures of nodes in the self-organising network of communication between project participants

Tabela 1 Ważone miary strukturalne sieci dla węzłów w samoorganizującej się sieci komunikacji pomiędzy uczestnikami przedsięwzięcia

Fig. 4. Weighted modularity (the colors of the nodes in the network correspond to the colors from the contractual structure and the formal organizational structure of the enterprise)

Rys.4. Ważona modułowość (kolory węzłów w sieci odpowiadają kolorom ze struktury umownej i formalnej struktury organizacyjnej przedsięwzięcia)

\section{ANALIZA SAMOORGANIZUJACYCH SIE SIECI KOMUNIKACJI POMIĘZY UCZESTNIKAMI BUDOWY OSIEDLA MIESZKANIOWEGO}

Słowa kluczowe: Analiza sieci społecznych (SNA), zarzadzanie w budownictwie, roboty budowlane

\section{STRESZCZENIE:}

W artykule zwrócono uwage na fakt, że wiele kluczowych decyzji w tymczasowych organizacjach budowlanych ,podejmowana jest w wyniku nieformalnych, poza umownych, niewynikających z formalnych struktur organizacyjnych relacji pomiędzy członkami tych organizacji. Te ukryte relacje wizualizowane mogą być w formie sieci społecznych a do ich analizy strukturalnej można użyć metody SNA (Social network analysis) Autorzy zwracają uwagę na fakt, że nieformalne, ukryte relacje pomiędzy uczestnikami są dynamiczne, gdyż stale się zmieniają (ewoluują) i dostosowują aby realizować cele przedsięwzięcia. Istotne jest więc monitorowanie tych samoorganizujących się sieci przez cały cykl realizacji tego przedsięwzięcia. Systematyczne wykrywanie różnych dysfunkcji uczestników w analizowanej sieci może być podstawą dla osób zarządzających tą organizacją do interwencji w strukturę relacji pomiędzy tymi uczestnikami. W najnowszych badaniach samoorganizujących się sieci w budownictwie badacze [24] skupiają głównie uwagę na fazie projektowej dużych przedsięwzięć np. infrastrukturalnych tym czasem jest potrzeba aby podobne badania dotyczyły tymczasowych organizacji tworzonych na potrzeby realizacji robót budowlanych. W artykule autorzy podjęli tą tematykę i zbadali samoorganizującą się sieć komunikacji pomiędzy uczestnikami budowy osiedla mieszkaniowego zlokalizowanego w Katowicach w Polsce. Analizowane przedsięwzięcie zlokalizowane jest w północnej części Katowic (około 3,5km od centrum miasta). W skład kompleksu wchodzą cztery budynki sześciokondygnacyjne (około $12000 \mathrm{~m} 2$ powierzchni użytkowej) z punktami usługowymi na parterze, garażami podziemnymi, infrastrukturą techniczną i drogową. Realizacja inwestycji rozpoczęła się w pierwszej połowie 2016 roku, a jej zakończenie planowane jest na wrzesień 2019 roku. Budżet inwestycji to $40 \mathrm{mln}$ złotych. Zasadniczym celem było porównanie formalnie wyznaczonej struktury organizacyjnej przedsięwzięcia z faktycznymi nieformalnymi relacjami jego uczestników w fazie realizacyjnej tego przedsięwzięcia. Analizowana była efektywność komunikacji pomiędzy uczestnikami przedsięwzięcia (w kontekście przekazywania informacji na temat: zakresu i rozwiązań projektowych, pojawiających się braków lub błędów w projekcie, oraz możliwości i zakresu wprowadzanych zmian) w fazie realizacji robót wykończeniowych. Dane zebrano z użyciem metody ankiety) od wszystkich 28 uczestników projektu. W przypadku poniższego badania uczestnicy 
przedsięwzięcia to zarówno jednostki indywidualne (np. kierownik budowy lub project manager) oraz organizacje mające swoich reprezentantów do komunikacji ( np. przedsiębiorstwa wykonawcze, biura projektów). Uczestnicy zostali poproszeni o wskazanie osób, z którymi przez ostatni miesiąc kontaktowały się na temat zakresu i rozwiązań projektowych, pojawiających się braków lub błędów w projekcie, oraz możliwości i zakresu wprowadzanych zmian dotyczących realizowanych w tym czasie robót wykończeniowych. Opis werbalny struktury komunikacji pomiędzy uczestnikami przedsięwzięcia przedstawiony został przy pomocy sieci relacji Węzły sieci symbolizują osoby indywidualne lub organizacje a łuki kierunki komunikacji pomiędzy nimi. W omawianym przypadku waga komunikacji (obciążenia łuku sieci) jest zdefiniowana przez dwie zmienne: częstotliwość i jakość [24]. Do określenia częstotliwości oraz jakości komunikacji posłużono się skalą Likerta. Analiza strukturalna otrzymanej sieci nieformalnych relacji w zakresie komunikacji na temat zakresu i rozwiązań projektowych, pojawiających się braków lub błędów w projekcie, oraz możliwości i zakresu wprowadzanych zmian dotyczących realizowanych w tym czasie robót wykończeniowych oparto na podstawowych charakterystycznych miarach strukturalnych sieci takich jak:

- gęstość (ang. density),

- stopień centralności (ang. degree centrality),

- pośrednictwo (ang. betweeness),

- bliskość (ang. closeness),

- modułowość (ang.modularity),

Analiza strukturalna przedmiotowej sieci pozwoliła na głębsze zrozumienie ukrytych, nieformalnych relacji pomiędzy uczestnikami tego przedsięwzięcia oraz wykrycie pewnych mankamentów i dysfunkcji tych uczestników co było podstawą do dalszych dyskusji. Jednym z ciekawszych rezultatów przeprowadzonej analizy było także wykrycie grup (społeczności) blisko ze sobą współpracujących uczestników przedsięwzięcia (głównie w ramach swoich branż: budowlana, instalacji elektrycznych oraz sanitarnych), jak również osobną społeczność jaką była grupa projektantów z koordynatorem do zmian lokatorskich (rysunek. 4).

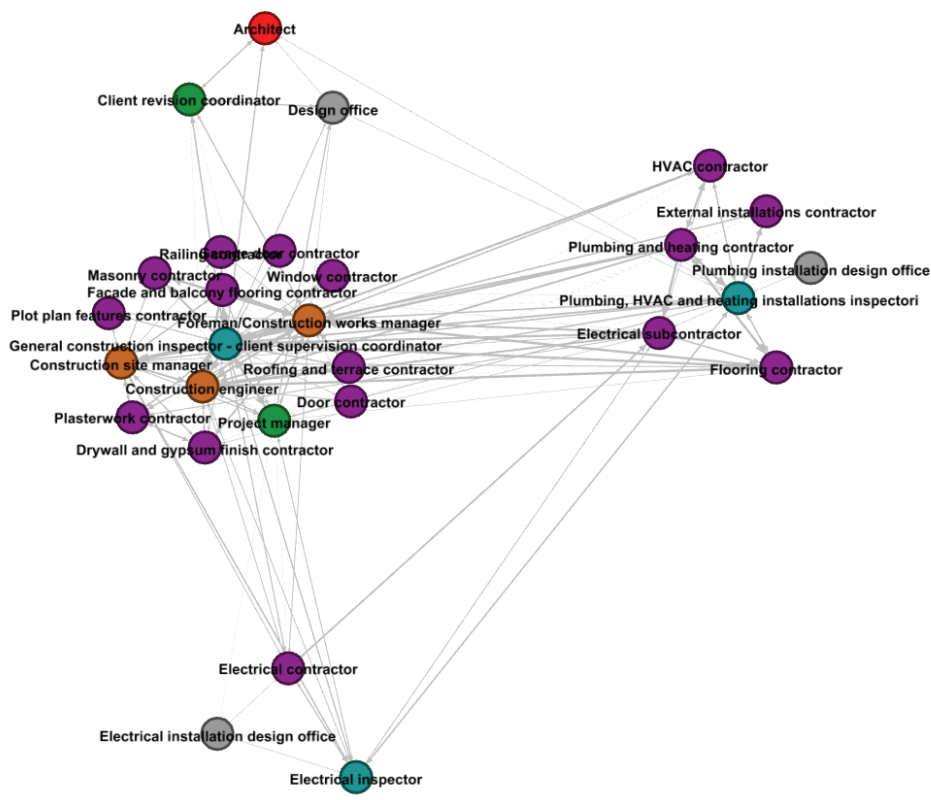

Rys.4. Ważona modułowość (kolory węzłów w sieci odpowiadają kolorom ze struktury umownej i formalnej struktury organizacyjnej przedsięwzięcia) 
Analiza takich społeczności może dostarczyć wiele cennych informacji na temat specyfiki i charakteru samoorganizujących się sieci uczestników przedsięwzięć budowlanych.

Autorzy podzielają pogląd zawarty w pracy [24], że zarzadzanie taką samoorganizującą się siecią może przynieść większe korzyści w kontekście realizacji celów przedsięwzięcia niż bazowanie na stosunkach umownych i formalnych relacjach (narzuconych przez odgórnie ustalone struktury organizacyjne) pomiędzy uczestnikami), W artykule autorzy wskazują także kierunki dalszych badań, które powinny skupiać się na wypracowaniu bardziej skutecznych, wiarygodnych metod pozyskiwania danych do wizualizowania (w formie sieci) ukrytych relacji pomiędzy uczestnikami przedsięwzięcia, gdyż badania ankietowe, mają swoje ograniczenia. W ramach kontynuacji badań powinno się analizować równolegle różne konteksty komunikacji pomiędzy uczestnikami realizowanego przedsięwzięcia co pozwoli na szersze zrozumienie cech samoorganiuzjących się sieci w fazie realizacji przedsięwzięcia. Ewentualne interwencję kadry menadżerskiej w tą ukrytą strukturę relacji pomiędzy uczestnikami przedsięwzięcia powinny być optymalizowane w kontekście osiąganych celów jak również uwzględniać (szczególnie istotne we wczesnej fazie rozwoju organizacji) ograniczenia takie jak koszty komunikacji w ramach danej organizacji [26]. W tym celu autorzy sugerują potrzebę opracowania skutecznych metod optymalizacji wspomagających te ewentualne interwencje, w strukturę takich sieci. 